\title{
Chemical composition of gahnite and degree of pegmatitic fractionation in the Borborema Pegmatitic Province, northeastern Brazil
}

DWIGHT R. SOARES ${ }^{1}$, HARTMUT BEURLEN ${ }^{2}$, ANA C.M. FERREIRA ${ }^{3}$ and MARCELO R.R. DA-SILVA ${ }^{2}$

${ }^{1}$ UFPE, NEG-LABISE, Departamento de Geologia. Av. Acadêmico Hélio Ramos s/n, Cidade Universitária, 50670-000 Recife, PE, Brasil

${ }^{2}$ UFPE, Departamento de Geologia. Av. Acadêmico Hélio Ramos s/n, Cidade Universitária, 50670-000 Recife, PE, Brasil

${ }^{3}$ UFCG, Departamento de Mineração e Geologia. Av. Aprígio Veloso, 882, 58109-970 Campina Grande, PB, Brasil

Manuscript received on October 19, 2005; accepted for publication on August 23, 2006;

presented by VALDEREZ FERREIRA

\begin{abstract}
Gahnite electron probe microanalyses from three pegmatites (Mirador, Capoeira and Quintos) of the Borborema Pegmatitic Province in northeastern Brazil allowed to determine molar compositions ranging from 86.22 to $95.41 \mathrm{~mol} \%$ gahnite $\left(\mathrm{ZnAl}_{2} \mathrm{O}_{4}\right), 1.51$ to $6.62 \mathrm{~mol} \%$ hercynite $\left(\mathrm{Fe}^{2+} \mathrm{Al}_{2} \mathrm{O}_{4}\right), 0.11$ to $5.89 \mathrm{~mol} \%$ spinel $\left(\mathrm{MgAl}_{2} \mathrm{O}_{4}\right), 1.48$ to 2.74 $\mathrm{mol} \%$ galaxite $\left(\mathrm{MnAl}_{2} \mathrm{O}_{4}\right)$, and $\mathrm{Zn} / \mathrm{Fe}_{\text {Total }}$ atomic ratios ranging from 11.53 to 60.87 . These data compared with gahnite compositions from albite subtype pegmatites from Cap de Creus, Spain ( $\mathrm{Zn} / \mathrm{Fe}_{\text {Total }}$ between 10 and 60$)$ and from the source granite of the Separation Rapids pegmatite field, Ontario, Canada $\left(\mathrm{Zn} / \mathrm{Fe}_{\mathrm{Total}}=3.5\right)$ indicate a high degree of fractionation of the studied pegmatites. This interpretation agrees with conclusions based on compositional data of tourmaline (vacancy in X-site 0.42 to 0.49 ), white mica ( $\mathrm{K} / \mathrm{Rb}$ between 8 and 33), feldspar ( $\mathrm{K} / \mathrm{Rb}$ between 8 and 109), garnet $\left(\mathrm{Mn} /\left(\mathrm{Mn}+\mathrm{Fe}^{2+}\right)\right.$ between 0.93 and 0.97$)$ and in $\mathrm{Nb}$-Ta oxides $\left(\mathrm{Mn} /\left(\mathrm{Mn}+\mathrm{Fe}^{2+}\right)>0.5\right)$ in the same pegmatites.
\end{abstract}

Key words: gahnite, rare-element granitic pegmatites, Borborema Pegmatitic Province, mineral chemistry.

\section{INTRODUCTION}

Gahnite is a spinel group mineral (with general formula $\mathrm{AB}_{2} \mathrm{O}_{4}$ ), with its $\mathrm{A}$ site being occupied mainly by $\mathrm{Zn}$ and the B site mainly by Al. According to Deer et al. (1981) gahnite occurs most commonly as accessory mineral in granitic pegmatites, "in metassomatic replacement veins" and as contact metamorphic mineral in marbles. An almost complete solid solution of gahnite is registered only with ordinary spinel $\left(\mathrm{MgAl}_{2} \mathrm{O}_{4}\right)$ according to these authors. The most common trace elements present in gahnite are $\mathrm{Li}, \mathrm{Rb}, \mathrm{Ba}, \mathrm{Ga}, \mathrm{Cu}$, and $\mathrm{Ti}$ (Von Knorring and Dearnley 1960). Cotelo Neiva et al. (1955) found up to $13.5 \mathrm{wt}$. $\% \mathrm{SnO}_{2}$, corresponding to $1.5 \mathrm{Sn}$ atoms per formula unit (apfu) from the Cabanas pegmatite in Portugal. Most commonly $\mathrm{Fe}^{2+}, \mathrm{Mg}$ and $\mathrm{Mn}^{2+}$

Correspondence to: Dwight Rodrigues Soares

E-mail: dwightsoares@yahoo.com.br may replace part of the $\mathrm{Zn}$ in the A site, while $\mathrm{Fe}^{3+}$ usually enters the $\mathrm{B}$ site replacing part of the $\mathrm{Al}$ in pegmatitic gahnites. Gahnite in pegmatites occurs usually associated with almandine-spessartite, muscovite, beryl, tourmaline, nigerite and, occasionally, with sphalerite as accessory minerals (Černý and Hawthorne 1982) or also with chrysoberyl (Alfonso et al. 1995).

According to the literature, gahnite does not occur in poorly fractionated, rare earth type pegmatites. Atomic ratios like $\mathrm{K} / \mathrm{Rb}, \mathrm{Al} / \mathrm{Ga}$ in mica, $\mathrm{K}$-feldspar, or $\mathrm{Mn} / \mathrm{Fe}$ in garnet and columbite, are frequently used as tracers of pegmatite fractionation and classification (Gordienko 1971, Černý et al. 1985, Černý 1991, Alfonso et al. 2003, etc.). In comparison, $\mathrm{Zn} / \mathrm{Fe}$ and $\mathrm{Mn} / \mathrm{Fe}$ ratios in spinel are still poorly explored with similar purpose (Batchelor and Kinnaird 1984).

Gahnite was found as accessory mineral in several pegmatites from the Borborema Pegmatitic Province 
(BPP) (e.g. Capoeira 1 and 2, Boqueirão, Caiçara, Pinga, etc.). In most of these pegmatites gahnite occurs only in a single unit of the zoned structure. Therefore, it is not possible to establish if there is a systematic compositional variation of gahnite during pegmatite crystallization. X-ray diffraction studies of gahnite from several pegmatites in the Acarí and Carnaúba dos Dantas areas in the State of Rio Grande do Norte were performed by Rodrigues da Silva (1961) but without a chemical control. Mineral chemistry data on gahnite are very scarce both, in the BPP (Ferreira et al. 2003; Soares et al. 2003) and in other pegmatitic provinces worldwide.

In the present study, compositional variations of gahnite from three pegmatites in the BPP are reported and evaluated as possible indicator of the degree of pegmatite fractionation, by comparison to other chemical parameters, like $\mathrm{K} / \mathrm{Rb}$ and $\mathrm{Al} / \mathrm{Ga}$ ratios in mica and feldspar, $\mathrm{Mn} / \mathrm{Fe}$ in garnet and alkali deficiency in tourmaline.

\section{MATERIALS AND METHODS}

Five crystals of gahnite (two from the Mirador, one from the Capoeira 2 and two from the Quintos pegmatites) were selected for electron microprobe analysis along cross-sections from core to rim. The data (total of 38 points) were obtained using a JEOL microprobe, model JXA-8600, with 5 WD and 1 ED spectrometer of the Institute of Geosciences of the University of São Paulo (IGUSP). Working conditions were $15 \mathrm{kV}, 20 \mathrm{nA}$, a beam diameter of 3 micrometer and 20 seconds acquisition times for all elements, using the internal standards wollastonite (for $\mathrm{Si}-\mathrm{K} \alpha$, and $\mathrm{Ca}-\mathrm{K} \alpha$ ), $\mathrm{TiO}_{2}$ (for $\mathrm{Ti}-\mathrm{K} \alpha$ ), anorthite (for Al-K $\alpha$ ), olivine (for $\mathrm{Fe}-\mathrm{K} \alpha$ ) spessartine (for $\mathrm{Mn}-\mathrm{K} \alpha)$ diopside $(\mathrm{Mg}-\mathrm{K} \alpha), \mathrm{ZnO}(\mathrm{Zn}-\mathrm{K} \alpha)$ and $\mathrm{Cr}_{2} \mathrm{O}_{3}$ $(\mathrm{Cr}-\mathrm{K} \alpha)$.

The structural formulae (in apfu) were calculated for a 32 oxygen formula according to Deer et al. (1981), considering the structural formula $\mathrm{R}_{8}^{2+} \mathrm{R}_{16}^{3+} \mathrm{O}_{32}$ in which $\mathrm{R}_{8}$ and $\mathrm{R}_{16}$ are the structural sites corresponding to $\mathrm{A}$ and $\mathrm{B}_{2}$ of the general formula $\mathrm{AB}_{2} \mathrm{O}_{4}$. The $\mathrm{Fe}^{2+}$ and $\mathrm{Fe}^{3+}$ proportions were estimated using the procedure suggested by Droop (1987).

\section{GEOLOGY}

The BPP, as defined by Scorza (1944), extends over an area of approximately $75 \times 150 \mathrm{~km}$, in the eastern- southeastern part of the Seridó Foldbelt in the Rio Grande do Norte Tectonic Domain, between $5^{\circ} 45^{\prime}$ and $7^{\circ} 15^{\prime}$ of southern latitude and $35^{\circ} 45^{\prime}$ and $37^{\circ} 00^{\prime}$ western longitude, in the States of Paraíba and Rio Grande do Norte, in Northeastern Brazil (Figure 1). The Seridó Foldbelt in this area is built up by the Jucurutu, Equador and Seridó Formations of the Neoproterozoic Seridó Group (Van Schmus et al. 2003). The rare-element mineralized granitic pegmatite formation is supposed to be related to granites of a late- to post-tectonic phase (Araújo et al. 2001) represented by the G4-granite group according to the classification by Jardim de Sá et al. (1981).

Most of the mineralized rare-element granitic pegmatites are intruded in garnet-cordierite and/or sillimanite-biotite schists of the topmost Serido Formation $(80 \%)$ and the directly underlying quartzites, metarkoses and metaconglomerates of the Equador Formation (11\%) (Da Silva et al. 1995). The remaining 9\% are hosted by gneisses and skarns of the Jucurutu Formation, by late G3 and G4 granites (Jardim de Sá 1984) or by gneisses and migmatites of the Paleoproterozoic basement sequence. The regional metamorphism of the Seridó Group reached the amphibolite grade of the low pressure-high temperature, Abukuma type metamorphism (E.S. Lima, unpublished data). Retro-metamorphism in the higher greenschist facies is observed related with the F4 deformation phase.

The studied pegmatites ("Altos"), are all hosted by quartzites (Mirador and Quintos) and metaconglomerates (Capoeira 2) of the Equador Formation, in central part of the BPP.

\section{Mirador Pegmatite}

The "Alto" Mirador pegmatite crosscuts the eastern limb of an antiform structure built up by the Equador Quartzites, $15 \mathrm{~km}$ northeastward from Carnaúba dos Dantas town. It extends over $150 \mathrm{~m}$ with a maximal thickness of $4 \mathrm{~m}$, dipping approximately with $80^{\circ}$ to $\mathrm{N} 20^{\circ} \mathrm{E}$. Along a complete cross section the following zones may be recognized, according to Ferreira et al. (2000):

- the wall zone in direct contact with the quartzites is formed by a medium grained aggregate of $\mathrm{K}$ feldspar, quartz, muscovite and biotite, and subordinated accessory tourmaline; 


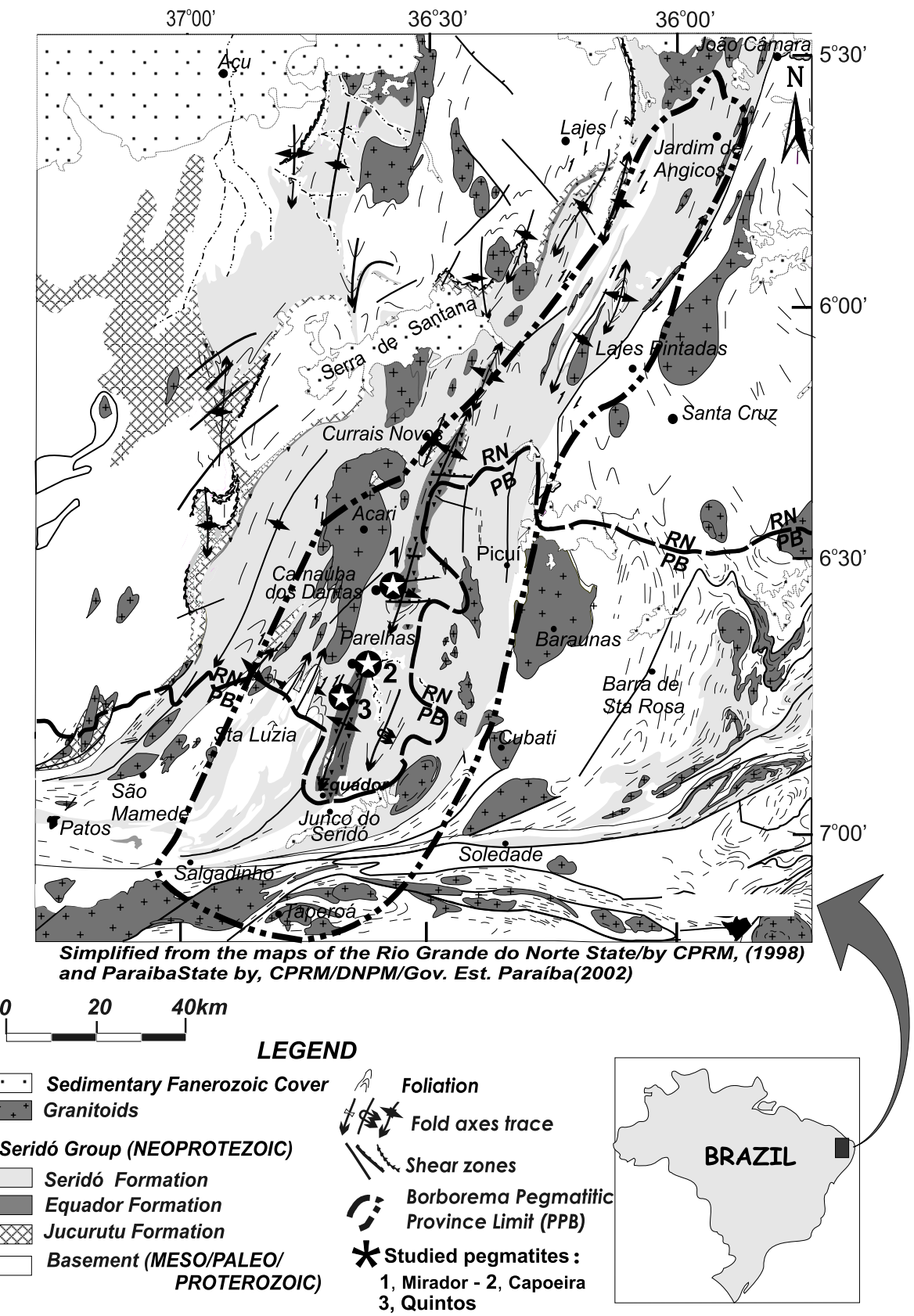

Fig. 1 - Location of the Mirador, Capoeira and Quintos pegmatites in the BPP on a simplified geological base.

- the external intermediate zone is formed by bands of graphic granite alternating with large K-feldspar crystals with accessory quartz and mica, and sporadic large white beryl crystals, and some fine digenite veinlets altered to malachite and chrysocole;

- the median intermediate zone is formed by quartz,
K-feldspar, muscovite, albite, lepidolite, black tourmaline (dravite) and occasional grains of gemologic minerals like spessartine, gahnite, rose colored euclase, and some bertrandite, tantalite, beryl, zircon and apatite. These accessory minerals are frequently enriched in small replacement bands rich in cleavelandite; 
- the up to $20 \mathrm{~cm}$ thick very discontinuous inner intermediate zone is formed mainly by muscovite, frequently altered K-feldspar and lepidolite with some accessory spessartine, in direct contact with the quartz core;

- the milky massive quartz core is irregular shaped and free of other minerals.

\section{CAPOEIRA 2 PEGMATITE}

The Capoeira 2 pegmatite is one of a group of, at least, four larger and many smaller (1 $\mathrm{m}$ or less) pegmatite veins within a cross section of $150 \mathrm{~m}$, dipping with 50 to $80^{\circ}$ to $\mathrm{SSW}$, crosscutting the gently $\left(30^{\circ}\right) \mathrm{NE}$ dipping Equador metaconglomerates at the northward plunging termination of the Serra das Queimadas antiform. From the contact inwards the following zones were recognized, according to D.R. Soares (unpublished data):

- the 5 to $50 \mathrm{~cm}$ thick border zone begins with an (a) one to two centimeter thick band formed by a sacharoidal, fine to medium grained aggregate of quartz, albite and microcline with sporadic accessory millimeter sized apatite crystals, followed by and grading to (b) a medium grained aggregate of quartz and feldspar with sporadic sub-centimeter sized spessartine and dravite grains and culminating with (c) a coarse grained aggregate dominated by quartz and comb or rosette like textured dravite, with the tips of crystals oriented inwards, into the wall zone.

- the wall zone is formed by a medium to coarse grained aggregate of albite, perthitic K-feldspar, muscovite and quartz, with sporadic blocks of graphic K-feldspar-quartz intergrowths and with frequent black tourmaline as accessory mineral. Rarely there are found millimeter-sized $(<5 \mathrm{~mm})$ idiomorphic emerald green gahnite and manganocolumbite crystals as inclusions in feldspar or muscovite. This is the most continuous zone in the pegmatite and grades into the intermediate zone by increasing size and number of blocky K-feldspar crystals with or without graphic quartz intergrowth.

- the external intermediate zone is continuous only in the upper portions of the pegmatite, formed by up to meter sized perthitic K-feldspar blocks in a quartz plus albite matrix. The external intermediate zone may contain sporadic "dissolution" cavities, up to $50 \mathrm{~cm}$ in diameter, with smoky or hyaline quartz+muscovite druses. This zone may be either in direct contact with the quartz core in the uppermost part of the pegmatite or followed by a seam of black tourmaline (schorl-dravite) rosettes at the transition to an inner intermediate albite cleavelandite) zone. In the lowest part of the pegmatite the blocky feldspar zone may lack completely.

- the inner intermediate "albite" zone frequently begins with an intense albitization of the blocky Kfeldspar of the external intermediate zone and/or a fringe of black tourmaline + albite rosettes followed by an almost pure albite aggregate culminating with a discontinuous fringe of, now blue- or bicolored, tourmaline (elbaite) at the contact with the quartz core. This elbaite forms up to $30 \mathrm{~cm}$ sized, cone shaped crystals oriented and growing into the quartz core, sometimes together with large tabular spodumene crystals. Both, spodumene and elbaite are most frequently intensively replaced by lepidolite. In a few cases small veins of albite beginning in this zone, crosscut the outer zones of the pegmatite and invade the hosting metaconglomerates to form meter sized albite-pegmatite apophyses, attesting the primary (melt-derivated) origin of this zone.

- the massive milky quartz core contains very rare isolated elbaite and spodumene crystals as only accessory minerals. This zone is very discontinuous forming a rosary of meter to decameter sized lenses.

In the other sheets of pegmatites of this group (Capoeira 1 to 4 ), in addition to these minerals, mainly associated with the "albite zone" and/or replacement pockets formed by muscovite selvages, there were found up to $50 \mathrm{~cm}$ large (primary) amblygonite, beryl and lithiophylite crystals, late blue apatite, uranmicrolite, tantalite, titanian ixiolite, and sulphides.

\section{Quintos Pegmatite}

The Quintos pegmatite, situated $9 \mathrm{~km} \mathrm{SW}$ from the Parelhas town, in the State of Rio Grande do Norte is famous 
because of its almost unique topmost gem quality production of "electric"-blue elbaitic "Paraíba Tourmaline". Extending over $150 \mathrm{~m}$ with a maximal thickness of $20 \mathrm{~m}$ and a dip between $30^{\circ}$ and $70^{\circ}$ to $100^{\circ} \mathrm{Az}$, it is enclosed discordantly by quartzites of the Equador Formation, at the western limb of the Serra das Queimadas antiform.

According to D.R. Soares (unpublished data), the internal structure of the pegmatite is formed by a border zone identical to that one described above for Capoeira 2 pegmatite, a small preserved wall zone, the main part of the wall zone and external intermediate zone being intensively replaced by albitization and lepidolitization processes, and a discontinuous albitic internal intermediate zone with a transition to the discontinuous quartz core identical to that described in Capoeira 2. The lemon green, 2 to $10 \mathrm{~mm}$ large, idiomorphic intensively fractured gahnite crystals are found mainly in the albitized external intermediate zone. They are usually associated to albite, muscovite and spessartine. Other primary accessory minerals of the pegmatite include brannerite, titanian ixiolite, uranmicrolite, caesian natrobistantite, (or caesian bismutomicrolite) according to Beurlen et al. (2005) green and rose beryl and spodumene.

\section{RESULTS AND DISCUSSION}

Chemical data of the studied gahnite crystals are summarized in Table I. They exhibit remarkably high $\mathrm{Zn}$ contents in the range of 6.97 to 7.64apfu, corresponding to 86 to $95 \%$ of zinc apfu in the A-site or of 86.22 to $95.41 \mathrm{~mol} \%$ gahnite, considering that the B site is occupied almost completely by $\mathrm{Al}$ ( $>99 \%$ of the B site) and that the presence of other elements detected in this site $\left(\mathrm{Fe}^{3+}, \mathrm{Ti}, \mathrm{Cr}, \mathrm{Si}\right)$ remains below the detection limit and/or near the analytical error. The contents of other minor elements found in A site, namely $\mathrm{Fe}, \mathrm{Mg}, \mathrm{Mn}, \mathrm{Ca}$ are consistent with data of near end-member gahnite referred to by other authors (Von Knorring and Dearnley 1960, Deer et al. 1981, Černý and Hawthorne 1982).

Backscattered electron images (BSE) of the gahnite grains in this case show idiomorphism and simple contacts with the surrounding K-feldspar and present a homogeneous gray pattern in backscattered images, indicating absence or very reduced compositional zoning and a primary origin by crystallization in equilibrium with K-feldspar and manganocolumbite (Figure 2).

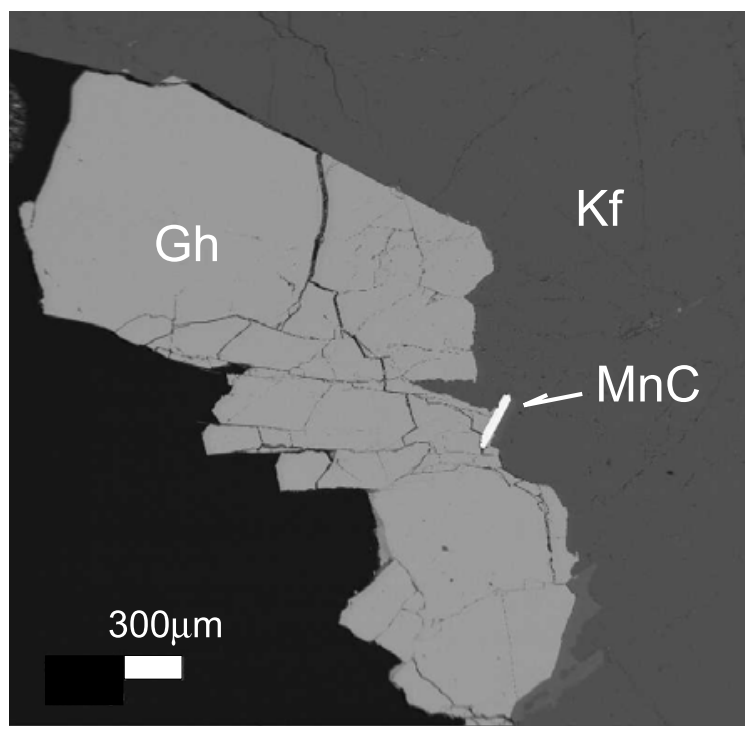

Fig. 2 - Homogeneous gray pattern of a grain of gahnite with a manganocolumbite inclusion, both included in K-feldspar from Capoeira 2 pegmatite.

The chemical compositions of gahnite are plotted in the $\mathrm{Zn}-\mathrm{Mg}-\mathrm{Fe}_{\text {Total }}$ diagram proposed by Batchelor and Kinnaird (1984) for gahnite characterization (Figure 3), including also data by Alfonso et al. (1995) for comparison. This figure shows that the compositional variations in a single crystal are much smaller than between different crystals of the same pegmatite (e.g. Mirador) and also that the ranges, both in single grains and in different grains of the same pegmatite, present a nearly linear distribution, with a narrow variation in the $\mathrm{Mg} / \mathrm{Fe}$ ratio, and a larger range in the $\mathrm{Zn} /\left(\mathrm{Mg}+\mathrm{Fe}_{\text {Total }}\right)$ ratio. This suggests that the $\mathrm{Mg} / \mathrm{Fe}_{\text {Total }}$ ratio is different for each deposit, remaining the same during the internal magma fractionation and that the $\mathrm{Zn}$ content in gahnite increases during the crystallization of the pegmatite at expense of $\left(\mathrm{Mg}+\mathrm{Fe}_{\mathrm{Total}}\right)$. It has to be investigated with a larger number of data if the $\mathrm{Mg} / \mathrm{Fe}_{\text {Total }}$ ratio is either a result of different degrees of $\mathrm{Fe}$ or $\mathrm{Mg}$ assimilation from the host rocks or differences in the degree of fractionation of the initial pegmatite-forming magma, or still, if this ratio is determined by different source granite magmas. It suggests also that in the BPP the $\mathrm{Zn} /\left(\mathrm{Mg}+\mathrm{Fe}_{\text {Total }}\right)$ and/ or $\mathrm{Mg} / \mathrm{Fe}_{\text {Total }}$ ratios may be more sensitive as indicators of the fractionation degree than $\mathrm{Zn} / \mathrm{Fe}_{\mathrm{Total}}$.

As first approach of correlation of gahnite compo- 


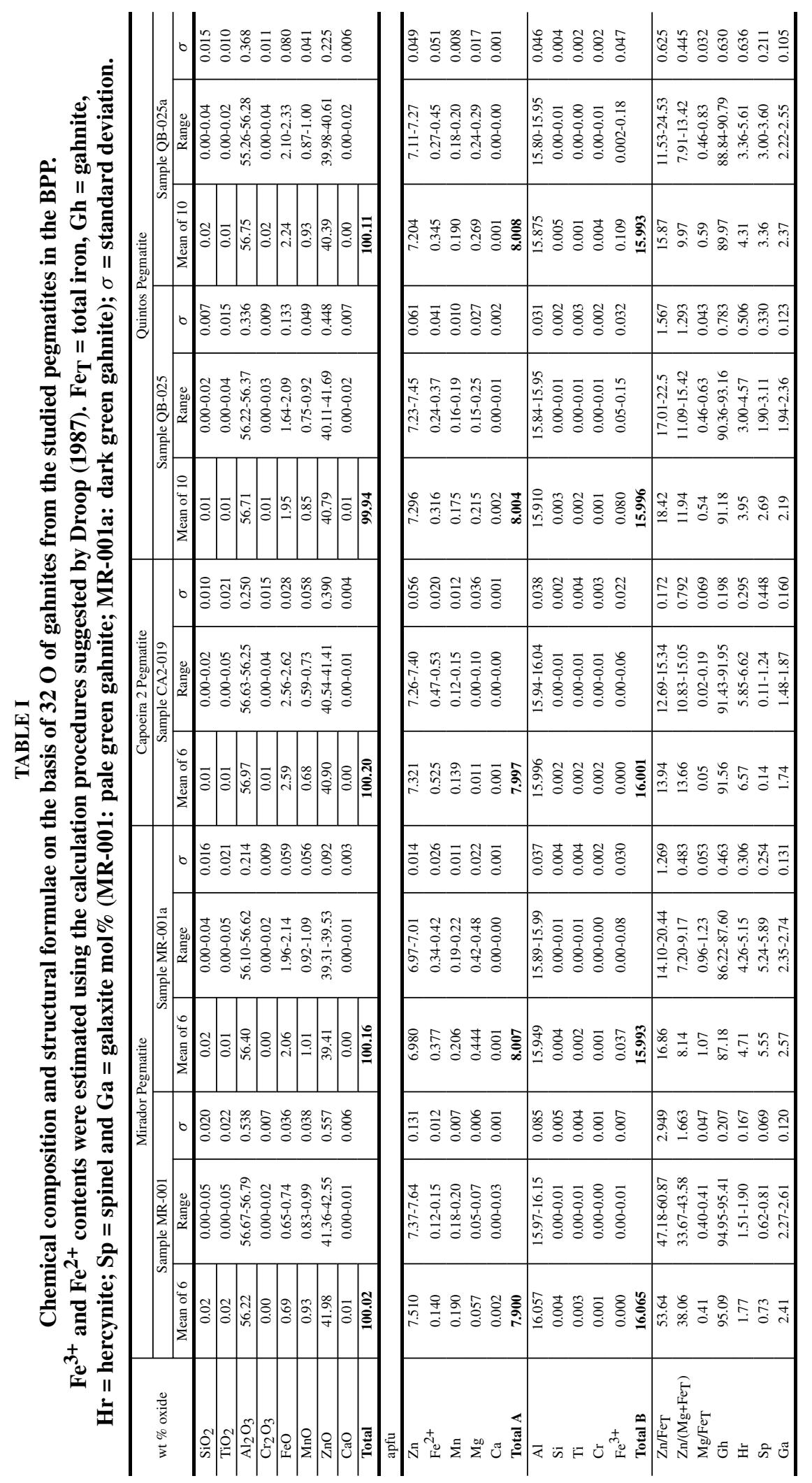




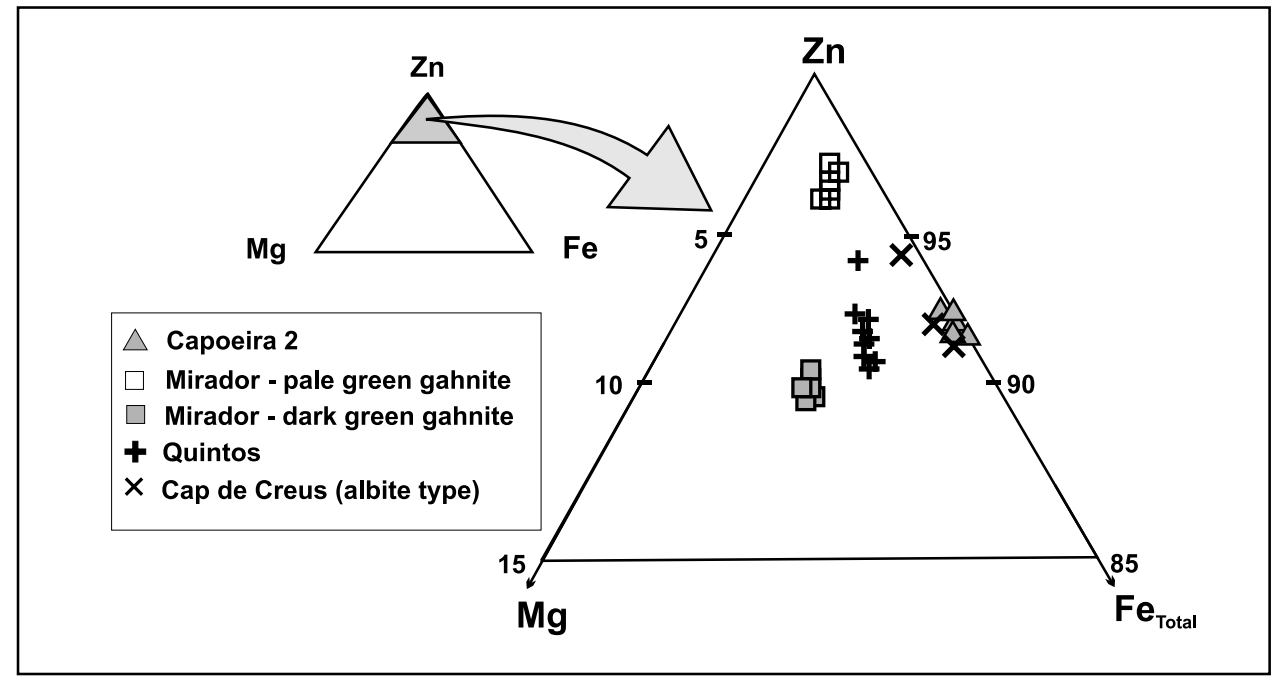

Fig. 3 - Chemical compositions of gahnite plotted in the $\mathrm{Zn}-\mathrm{Fe}_{\text {Total }}-\mathrm{Mg}$ diagram, as suggested by Batchelor and Kinnaird (1984), including data from Cap de Creus albite type pegmatite (Spain), according to Alfonso et al. (1995) for comparison.

sitions with magma evolution, Batchelor and Kinnaird (1984) suggested that Mg contents in gahnite decrease with the degree of magma fractionation from anatectic granites derived from biotite schists $(\mathrm{MgO}=1.55$ to $3.27 \mathrm{wt} . \%)$ to more fractionated igneous granites $(\mathrm{MgO}$ $=0.61 \mathrm{wt} . \%)$ and, finally to evolved pegmatites. The same authors, in accordance with data by Taylor (1965), apud Batchelor and Kinnaird (1984), suggested that the $\mathrm{Zn} / \mathrm{Fe}_{\text {Total }}$ ratio increases with the magma differentiation, with values of $\mathrm{Zn} / \mathrm{Fe}_{\text {Total }}>3.8$ typical for igneous gahnites contrasting with values below 3.8 for gahnites of metamorphic or palingenetic origin. In the present case, the $\mathrm{Zn} / \mathrm{Fe}_{\text {Total }}$ ratio ranging between 12.69 to 60.87 , the high gahnite content ( 86.22 to $95.41 \mathrm{~mol} \%$ ) and the low proportions of hercynite (1.51 to $6.62 \mathrm{~mol} \%$ ), spinel ( 0.11 to $5.89 \mathrm{~mol} \%$ ) and galaxite (1.48 to $2.74 \mathrm{~mol} \%$ ) are indicative of an igneous origin.

A high fractionation degree of the studied pegmatites in BPP is indicated by comparison with similar values obtained by Alfonso et al. (1995, 2003) for gahnite in albite type pegmatites of Cap de Creus (Spain, data included in Figure 4), and in comparison with data by Tindle and Breaks (1998) for gahnite in the source granite of the Separation Rapids pegmatite field with $\mathrm{Zn} / \mathrm{Fe}_{\text {Total }}$ of 3.5 and $76.7 \mathrm{~mol} \%$ gahnite. The high degree of frac- tionation is also confirmed by compositional data on tourmaline (vacancy in X-site 0.42 to 0.49 ), white micas $(\mathrm{K} / \mathrm{Rb}$ between 8 and 33$)$, feldspars $(\mathrm{K} / \mathrm{Rb}$ between 8 and 109), garnet $(\mathrm{Mn} /(\mathrm{Mn}+\mathrm{Fe})$ between 0.93 and 0.97$)$ and in $\mathrm{Nb}$-Ta oxides $(\mathrm{Mn} /(\mathrm{Mn}+\mathrm{Fe})>0.5)$ in the same pegmatites by comparison with similar data from other pegmatite fields throughout the world.

For a better understanding of the substitution mechanisms involving $\mathrm{Zn}, \mathrm{Mg}, \mathrm{Fe}$, and $\mathrm{Mn}$ in the spinel structure Batchelor and Kinnaird (1984) also proposed the plot of $\left(\mathrm{Fe}_{\mathrm{Total}}+\mathrm{Mg}\right) / \mathrm{Al}$ versus $(\mathrm{Zn}+\mathrm{Mn}) / \mathrm{Al}$. In the same diagram it should be also possible to evaluate the degree of the magma evolution during the crystallization of the spinel. The data obtained in the present study are shown in this diagram in Figure 5. A general distribution of the data follow roughly the fractionation direction suggested by Batchelor and Kinnaird (1984), with the darker crystal of the Mirador pegmatite at the least fractionated end, followed successively by data from Quintos (similar to Cap de Creus data), Capoeira 2 and the lighter crystal from Mirador. A vertical distribution of the data from Capoeira 2 and of the light crystal from Mirador, indicate that the $(\mathrm{Zn}+\mathrm{Mn})$ enrichment within these crystals occurs with constant $(\mathrm{Fe}+\mathrm{Mg})$ values. In Figure $4, \mathrm{Zn}-\mathrm{Mn}-\left(\mathrm{Fe}_{\mathrm{Total}}+\mathrm{Mg}\right)$, it is possible to verify 


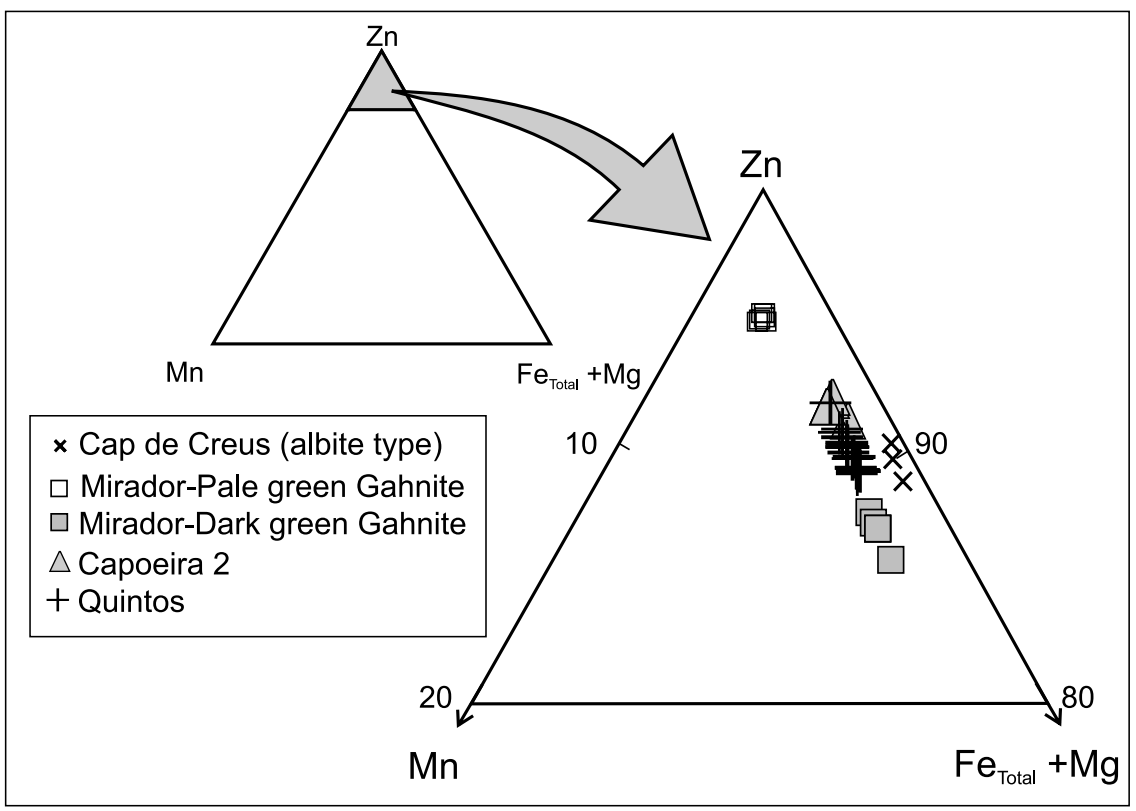

Fig. 4 - Chemical compositions of gahnite plotted in the $\mathrm{Zn}-\mathrm{Mn}-\left(\mathrm{Mg}+\mathrm{Fe}_{\mathrm{Total}}\right)$ diagram, including data from Cap de Creus albite type pegmatite (Spain), according to Alfonso et al. (1995) for comparison.

that the $\mathrm{Mn} /\left(\mathrm{Mg}+\mathrm{Fe}_{\mathrm{Total}}\right)$ ratio remains constant for data of the same grains and pegmatites, indicating that there is no $\mathrm{Mn}$ fractionation during the crystallization of the pegmatite, and that the vertical distribution of single grain data in Figure 5 is mainly due to $\mathrm{Zn}$ enrichment during internal fractionation.

\section{CONCLUSIONS}

Contents of gahnite (86.22 to $95.41 \mathrm{~mol} \%$ ) and high $\mathrm{Zn} / \mathrm{Fe}_{\text {Total }}$ ratios (13.85 to 63.17 ) in all studied spinel crystals from the Mirador, Quintos and Capoeira pegmatites in the BPP are higher than most data in literature and indicate a high degree of fractionation of the pegmatite-forming magma from which these crystals originated, similar or higher to data referred to by Alfonso et al. (1995) for gahnite from albite subtype pegmatites in the Cap de Creus pegmatite field in Spain.

This interpretation is in agreement with other mineral chemistry data available for the same pegmatites, namely:

a) $\mathrm{Mn} /(\mathrm{Mn}+\mathrm{Fe} 2+)$ ratios (0.93 to 0.97$)$ in garnets from Mirador according to Eeckhout et al. (2002), from Capoeira $2(\mathrm{Mn} /(\mathrm{Mn}+\mathrm{Fe} 2+)$ between 0.67 and
$0.72)$ and Quintos $(\mathrm{Mn} /(\mathrm{Mn}+\mathrm{Fe} 2+)$ between 0.70 and 0.92) obtained by D.R. Soares (unpublished data).

b) $\mathrm{K} / \mathrm{Rb}$ ratios in white micas (12-33) and $\mathrm{K}$-feldspars (32 to 109) in Capoeira 2 according to D.R. Soares (unpublished data).

c) $\mathrm{K} / \mathrm{Rb}$ ratios in white micas ( 8 to 10 ) and $\mathrm{K}$-feldspars (8 a 10) and high Cs contents (up to 1628 ppm) in K-feldspars from the Quintos pegmatite according to D.R. Soares (unpublished data).

d) Tourmaline with high vacancy in X-site (0.42 to 0.49), according to D.R. Soares (unpublished data).

The data so far obtained suggest that $\mathrm{Fe} / \mathrm{Mg}$ ratios remain constant during the crystallization of the studied pegmatites but are different in the three studied cases while the $\mathrm{Zn}(+\mathrm{Mn}) / \mathrm{Fe}$ ratios increase during the gahnite crystallization and pegmatite fractionation.

It is important to state that the results must be considered as preliminary because all of them refer to pegmatites enclosed in quartzites and metaconglomerates of the Equador Formation, while data from pegmatites enclosed in biotite-schists or granites are still inexistent. 


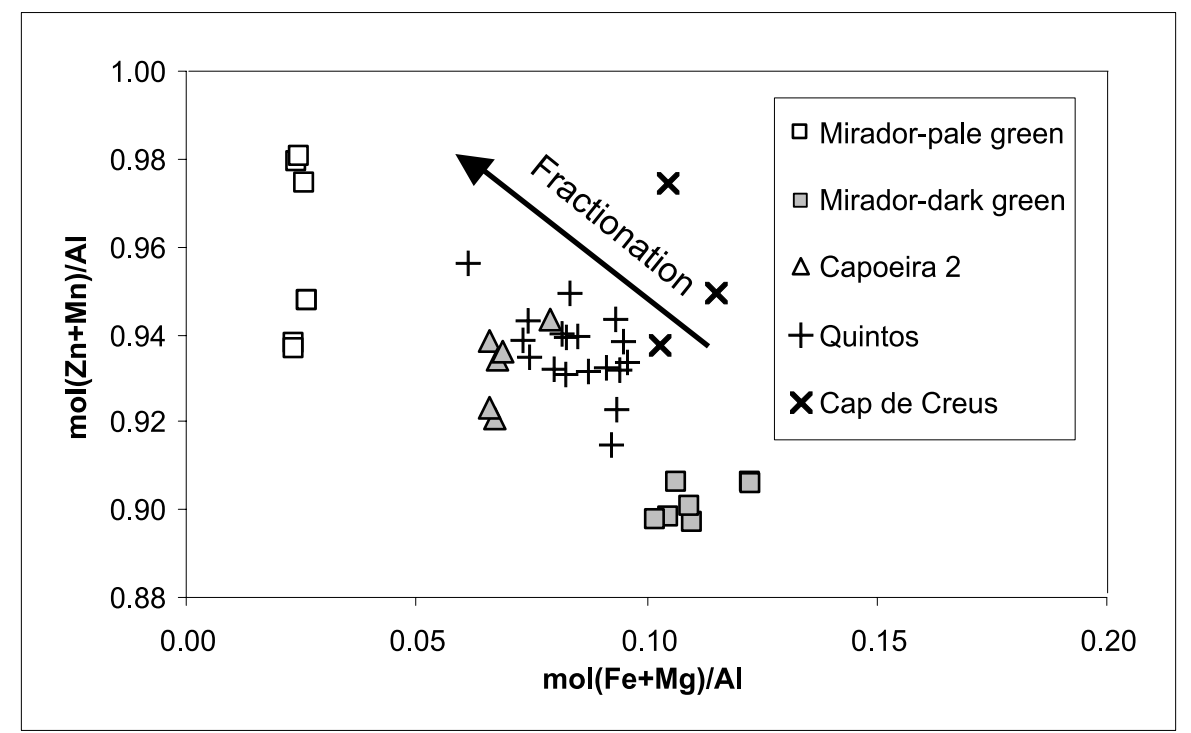

Fig. 5 - Chemical compositions of gahnite plotted in the $\left(\mathrm{Fe}_{\mathrm{Total}}+\mathrm{Mg}\right) / \mathrm{Al}$ versus $(\mathrm{Zn}+\mathrm{Mn}) / \mathrm{Al}$ diagram, as suggested by Batchelor and Kinnaird (1984), including data from Cap de Creus albite type pegmatite (Spain), according to Alfonso et al. (1995) for comparison.

The influence of $\mathrm{Fe}$ (and $\mathrm{Mn}$ and $\mathrm{Mg}$ ) assimilation from wall-rocks can still not be evaluated.

\section{ACKNOWLEDGMENTS}

This study was supported by Conselho Nacional de Desenvolvimento Científico e Tecnológico (CNPq) grants APQ 470199/01 and PQ 352181/92-3 and Coordenação de Aperfeiçoamento de Pessoal de Nível Superior (CAPES) grant AEX 0728/04-7. Technical support by Excelso Ruberti and Marcos Mansueto, from the EPMA lab of the Instituto de Geociências da Universidade de São Paulo (IG-USP) is also greatly acknowledged. The authors appreciated and acknowledge helpful comments and suggestions by two anonymous reviewers.

\section{RESUMO}

Análises via microssonda eletrônica de gahnita de três pegmatitos (Mirador, Capoeira e Quintos) da Província Pegmatítica da Borborema, no Nordeste do Brasil, permitiram estabelecer uma composição molar variando entre 86,22 e 95,41 mol\% de gahnita $\left(\mathrm{ZnAl}_{2} \mathrm{O}_{4}\right), 1,51$ e $6,62 \mathrm{~mol} \%$ de hercinita $\left(\mathrm{Fe}^{2+} \mathrm{Al}_{2} \mathrm{O}_{4}\right)$, 0,11 e 5,89 mol\% de espinélio $\left(\mathrm{MgAl}_{2} \mathrm{O}_{4}\right), 1,48$ e 2,74 mol\% de galaxita $\left(\mathrm{MnAl}_{2} \mathrm{O}_{4}\right)$ e relação $\mathrm{Zn} / \mathrm{Fe}_{\text {Total }}$ variando entre 11,53 e 60,87 . Estes dados comparados com os de gahnita dos pegmatitos subtipo albita de Cap de Creus, Espanha ( $\mathrm{Zn} / \mathrm{Fe}_{\text {Total }}$ variando entre 10 e 60) e gahnita de fonte granítica do campo pegmatítico Separation Rapids, Ontário, Canadá ( $\mathrm{Zn} / \mathrm{Fe}_{\text {Total }}$ $=3,5$ ) indicam um alto grau de fracionamento dos pegmatitos estudados. Esta interpretação está de acordo com conclusões baseadas em dados de turmalina (vacância no sítio $\mathrm{X}$ variando entre 0,42 a 0,49$)$, mica clara $(\mathrm{K} / \mathrm{Rb}$ variando entre 8 e 33), feldspato (K/Rb variando entre 8 e 109), granada $\left(\mathrm{Mn} /\left(\mathrm{Mn}+\mathrm{Fe}^{2+}\right)\right.$ variando entre 0,93 e 0,97$)$ e óxidos de $\mathrm{Nb}-\mathrm{Ta}$ $\left(\mathrm{Mn} /\left(\mathrm{Mn}+\mathrm{Fe}^{2+}\right)>0,5\right)$, nos mesmos pegmatitos.

Palavras-chave: gahnita, pegmatitos graníticos de elementos raros, Província Pegmatítica da Borborema, química mineral.

\section{REFERENCES}

Alfonso AP, Corbella MC and Melgarejo JC. 1995. $\mathrm{Nb}$-Ta minerals from the Cap de Creus pegmatite field, eastern Pyrenees: distribution and geochemical trends. Mineral and Petrol 55: 53-69.

Alfonso AP, Melgarejo JC, Yusta I and Velasco F. 2003. Geochemistry of feldspars and muscovite in granitic pegmatite from Cap de Creus field, Catalonia, Spain. Can Mineral 41: 103-116.

Araújo MNC, Alves da Silva FC and Jardim de SÁ EF. 2001. Pegmatite emplacement in the Seridó Belt, 
northeastern Brazil: late stage kinematics of the Brasiliano orogen. Gondwana Res 4: 75-85.

BATCHELOR RA AND KINNAIRD JA. 1984. Gahnite compositions compared. Mineral Mag 48: 425-429.

Beurlen H, Soares DR, Thomas R, Prado-Borges LE AND CASTRo C. 2005. Mineral chemistry of tantalate species new in the Borborema Pegmatitic Province, Northeast Brazil. An Acad Bras Cienc 77: 169-182.

ČERNÝ P. 1991. Rare-element granitic pegmatites. Part I: Anatomy and internal evolution of pegmatite deposits. Geosci Can 18: 49-67.

ČERnÝ P AND HAWTHORNE FC. 1982. Selected peraluminous minerals. In: GRANitic Pegmatites IN SCIENCE AND Industry (ČERnÝ P ED), Mineral Ass Canada (Short Course) 8: 163-186.

ČERnÝ P, MEINTZER RE AND ANDERSOn AJ. 1985. Extreme fractionation in rare-element granitic pegmatites: selected examples of data and mechanisms. Can Mineral 23: $381-421$.

Cotelo Neiva JM, Rimsky A AND SANDrÉA A. 1955. Sur une variété de gahnite stannifère de Cabanas (Portugal). Bull Soc Fran Mineral Cristal 78: 97-105.

CPRM. 1998. Programa Levantamentos Geológicos Básicos do Brasil. Caicó (Folha SB.24-Z-B) - Estados da Paraíba e Rio Grande do Norte - Escala 1:250.000 - Geologia e Metalogênese. Brasília, DF, Brasil, 70 p (mais anexos).

CPRM, DNPM, Governo do Estado da PARAÍbA. 2002. Geologia e Recursos Minerais do Estado da Paraíba. Recife, PE, Brasil, 142 p (mais anexos).

Da Silva MRR, Holl R and Beurlen H. 1995. Borborema Pegmatitic Province: geological and geochemical characteristic. J South Am Earth Sci 8: 355-364.

DeER WA, Howie RA AND Zussman J. 1981. Minerais Constituintes das Rochas - Uma Introdução. Fundação Colouste Gulbenkian. Lisboa, Portugal, 558 p.

DROOP GTR. 1987. A general equation for estimating $\mathrm{Fe}^{3+}$ concentrations in ferromagnesian silicates and oxides from microprobe analyses, using stoichiometric criteria. Mineral Mag 51: 431-435.

Eeckhout SG, Castañeda C, Ferreira ACM, SabioNi ACS, De Grave E AND VASConcelos DCL. 2002. Spectroscopic studies of spessartine from Brazilian pegmatites. Amer Mineral 87: 1297-1306.
Ferreira ACM, Ferreira JAM and TAVAres JF. 2000. O pegmatito Alto Mirador: descrição e mineralogia. XVIII Simpósio de Geologia do Nordeste. Recife, PE, Brasil, 157 p.

FERrEIRA ACM, SoARES DR AND FERrEIRA JAM. 2003. Gahnitas gemas do pegmatito Alto Mirador, Região do Seridó (RN). XX Simpósio de Geologia do Nordeste. Fortaleza, CE, Brasil, 45 p.

Gordienko VV. 1971. Concentration of $\mathrm{Li}, \mathrm{Rb}$ and $\mathrm{Cs}$ in potash feldspar and muscovite as criteria for assessing the rare metal mineralization in granite pegmatites. Intern Geol Rev 13: 134-142.

JARDIM DE SÁ EF. 1984. Geologia da região do Seridó: reavaliação de dados. XI Simpósio de Geologia do Nordeste, Natal, RN, Brasil, p. 278-296.

JARDim DE SÁ EF, LEGRAND JM AND MCREATH I. 1981. Estratigrafia de rochas granitóides da região do Seridó (RN-PB) com base em critérios estratigráficos. Rev Bras Geoc 11: 50-57.

Rodrigues DA Silva R. 1961. Mineralogia da gahnita de Acarí e Carnaúba dos Dantas (R.G.N.) Boletim do Instituto de Geologia da Universidade do Recife. Mineralogia 1: 21-33.

Scorza EP. 1944. Província Pegmatítica da Borborema. DNPM/DGM (Boletim 112). Rio de Janeiro, RJ, Brasil, $55 \mathrm{p}$.

SoAres DR, Beurlen H AND Ferreira ACM. 2003. Química mineral da gahnita do pegmatito Capoeira, Província Pegmatítica da Borborema (PPB), NE do Brasil. XX Simpósio de Geologia do Nordeste. Fortaleza, CE, Brasil, 55 p.

Tindle AG AND BREAKS FW. 1998. Oxides minerals of the Separation Rapids rare-element granitic pegmatite group, northwestern Ontário. Can Mineral 36: 609-635.

VAN Schmus WR, Brito Neves BB, Williams IS, HaCkspacher PC, Fetter, AH, Dantas EL AND BABINSKi M. 2003. The Seridó Group of NE Brazil, a late Neoproterozoic pre- to syn- collisional basin in west Gondwana: insights from SHRIMP U-Pb detrital zircon ages and Sm-Nd crustal residence (TDM) ages. Precam Res 127: 287-327.

Von KNORRING O AND DEARnLEy R. 1960. The Lewisian pegmatites of the South Harris, Outer Hebrides. Mineral Mag 32: 366-378. 